\title{
Indian Financial System- A Descriptive Study
}

\author{
MANOJ KUMAR
}

\section{Assistant Professor, Business Management and Commerce Department, IEC University Baddi, HP}

India.

\begin{abstract}
A money related framework assumes a fundamental job in the monetary development of a nation. It moderate between the individual who spare a piece of their salary and the individuals, who put resources into resources. The economic growth of a country like India is totally depended upon a financial system. A financial system is a system that interchange the funds between the peoples or lenders and depositors. A money related framework comprises budgetary establishments, monetary markets, budgetary instruments, and monetary administrations.
\end{abstract}

This paper focuses on the Indian financial system, its components and major weakness contain in Indian financial system. It is based on secondary data and information which is taken from secondary source such as journals and books etc.

Keywords: Budgetary establishments, monetary markets, budgetary instruments, monetary administrations, lenders and depositors.

\section{INTRODUCTION}

Money is necessary for every activity of man- individual, business and governments. It is also playing an important role in production and distributions and also country growth. The availability of money when needed or required is known as finance. Money is a real existence blood of each action of human. But money and finance does not directly helpful to economic growth of country and development.

The development of a country is mostly depended upon its financial system. The developing country like India, financial system is play important role for growth of economy. Financial system is operating at national as well as international level. The financial system, helps to promote investments, promoting payments services, monitoring investments and managing and transforming risks.

The Indian financial system consists Regulators (like MoF, SEBI, IRDA etc ), financial institutions(like Banking \& Non-Banking ), financial instruments(like Mutual Funds, shares, etc.), financial markets(like Capital markets \& Money markets. ), financial services(like leasing, hire purchases, portfolio management \& Merchant banking etc.).

\section{LITERATURE SURVEY}

Levine (1997) explain importance of financial system and also define the relationship between growth and quality provided by the financial system.

Arora (2005) conducted a study on services provided by financial markets of south Africa and some suggestions and lessons from them for the financial services. He observed that these two markets different to each other's, due to geographical populations sizes, incomes and political environments etc.

Allen, \& De (2007) in their examination brought up that lately India, stays a creating nation with all its sheen and amazing capital market execution, yet at the same time the money related framework prohibits about $40 \%$ of the population for the most part the provincial poor. They likewise featured the effectiveness and adequacy of money related part, privatization progress and significant changes of banking division, important standards of corporate administration and the significance of microfinance as a gainful strategy for destitution easing and advancement in India.

Sen \& kar (2014) disclose in their investigation to look at the political and foundation causes in India's development. They suggested that, there are no political and other legislation is essential for economic growth in India.

Vaishali Doshi (2016), "defined that, economic development of a national is totally dependence upon the national financial system".

Sanjay Kumar (2017), stated that India has a monetary framework, that is directed by self- governing regulators in the sector of banking \& Insurance and so many sectors.

International Monetary Fund (IMF) Said that, India's financial system is facing a problem $\&$ challenges regarding high non- performing assets and slow developing balance sheet testing by banking system.

Objective of the Study:

1. To define the functions and components of Indian Financial system.

2. To define weakness that containing in Indian Financial System. 


\section{RESEARCH METHODOLOGY}

The data for this study is collected from secondary sources like, reputed journals, magazines, books and reputed websites.

\section{FUNCTIONS AND COMPONENTS OF INDIAN FINANCIAL SYSTEM}

The monetary arrangement of a nation performs different important capacities for the financial development and advancement of the nation. The fundamental elements of a monetary framework are examined as follows:

Growth of an Indian economy: Indian financial system is key point for growth of an economy. Though financial system a developing country, like India grow very fast. It also depended on the infrastructure facilities available in the country. Lack of key industry like coal, Oil and power, development of other industry will be hampered. Therefore, financial system provided funds for the growth of infrastructure of industries.

Development of both domestic and foreign trade: Indian financial system helps to promote both domestic and as well as foreign trade. Financial institutions and financial instruments are used for this purpose such as bills, shares etc. Foreign trade such as pre-shipment finance and post shipment finance is provided by banks.

Raising funds: Though financial system, the state or central governments raising short term or long terms funds by issuing of securities \& bounds in capital market, money market along with foreign exchange market that enable to businessmen, government as well as industries to meet their credit requirements.

Financial system is also helpful to growth of capital market: Every business require capital to growth of that business. There are two sorts of capital required for enterprises to successful running the business namely fixed capital and working capital. Fixed capital is used for beginning the business and its duration is long such as capital required for purchasing land \& building and machinery and so on, whereas working capital is used for performing day to day operations such as purchasing raw materials, paid salaries to employees. Therefore, financial system plays a vital role to growth of capital market.

Saving and Investments relationship: The financial system, efficiently direct the flow of saving and investment in the economy. Banks play a vital role. They allow depositors invest money in various schemes like fixed deposits \& recurring deposits by offering attractive interest rates. These saving are transferred by the banks to different businessmen in the form of loan or credit which are involved in production and distribution process.

Foreign Exchange Market: Foreign exchange market helps to exporters and importers to raising the funds though national and international transactions. This market also provides opportunities for banks to invest funds and earn profit.

Generate Employment: A effective financial system also helps to generate employments opportunities with economy. It provides funds or cash for establishing the industries, which need for employees for doing production of goods both organized and unorganized sectors.

\section{COMPONENTS OF INDIAN FINANCIAL SYSTEM}

Financial system consists financial institutions, financial instruments, financial markets and financial services. There are following diagrams that shows all elements and components of Indian financial system.

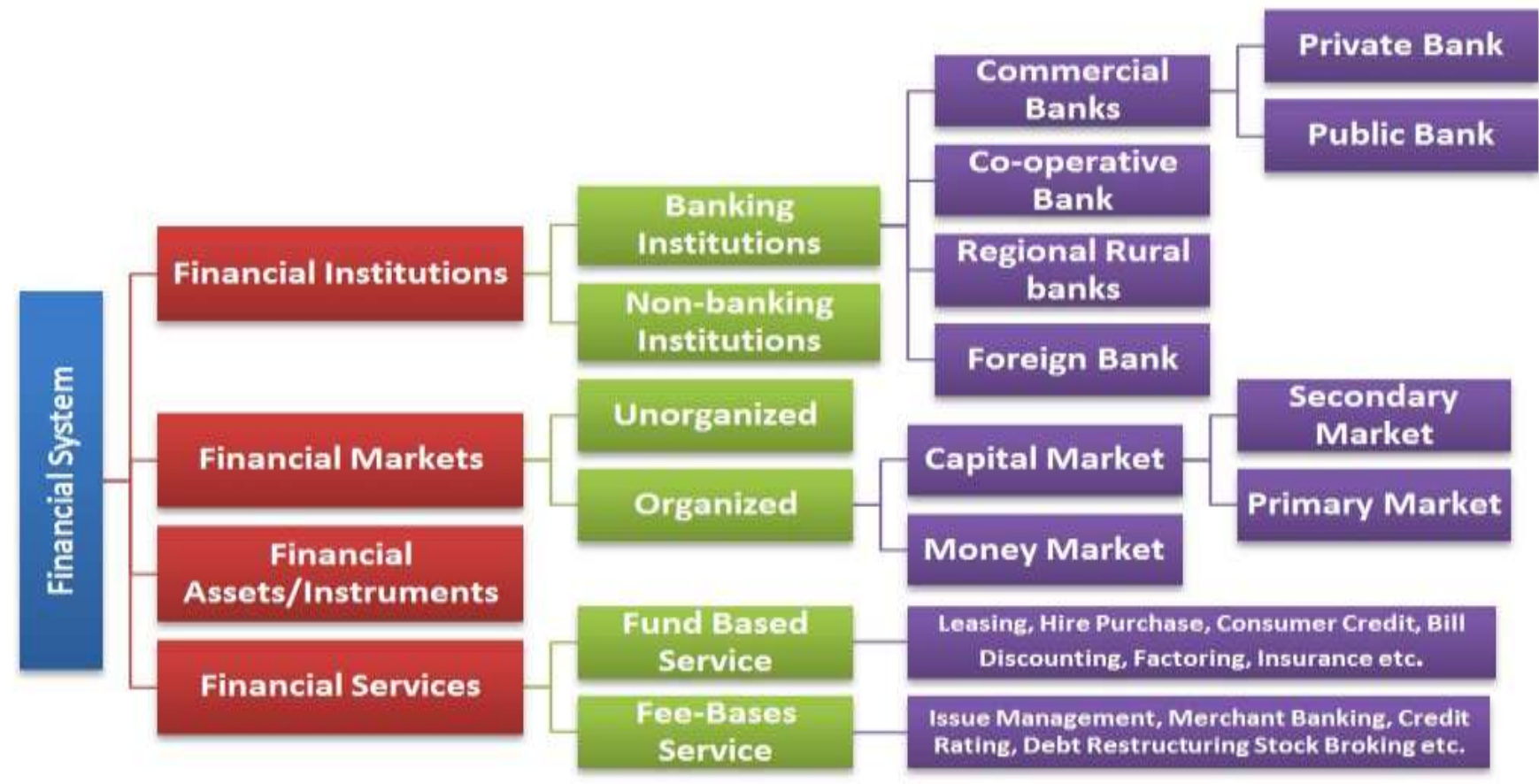


Financial Institutions: Financial institutions are those institutions that collect money from investors, and put that money into different sectors to earn income and profit. We can say that a financial institution are those institutions that are provides financial services for its clients and their members. Financial institutions further divided into two types such as banking institutions like commercials banks and non-banking institutions like IRDA and SEBI etc.

Financial Markets: A market where financial assets and financial products are created and transferred is called financial market. It is a market where financial products are selling or purchasing. Financial market further divided in to two types namely capital market and money market. Capital market is a market where companies raising their long-term funds. It consists primary market and secondary market. Primary market is also called as New Issue Market (NIM), in which securities are introduce firstly in this market, but in the case of secondary market buying and selling of already issued securities. Money market can be defined as a market for short term debt securities with a maturity of one year or less than one year.

Financial Instruments: Financial instruments are those instruments that deals with financial market. It includes cash deposits, loans, account receivable, banks notes that provide a claim against a person to pay either a specific amount on a certain date.

Financial Services: Financial services are those services that are provides by financial institutions and other financial agencies to their valuable clients and their members. It includes leasing, hire purchase, bill discounting, merchant banking, credit rating and portfolio management and so on.

\section{WEAKNESS THAT CONTAINING IN INDIAN FINANCIAL SYSTEM.}

Lack or proper co- ordination between financial institutions, because there are a large number of financial intermediate between them, such as government authorities. Due to lack of this co- ordination Indian financial system was failed in my cases.

It is very difficult some times to run government regulations to implements in financial world or system.

The predominance of money related leads the unfortunate budgetary practices among corporate clients, state when corporate undertaking takes monetary emergencies, the monetary establishments grant an enormous utilization of obligation than is justified. This will aggravate the conditions.

A portion of the money related foundations appreciate monopolistic market structure. Some monetary establishments are huge, in this way, they appreciate a wastefulness in their working or such sort of botch.

\section{CONCLUSION}

Economic growth and development of economy is totally depended upon a effective financial system. It intermediate between the flow of funds belongs to those who have saving a part of their income and those who invest in productive assets. In order to make financial system is more effective and efficient, there is a need to control all the components of financial system. Also make a necessary rules and regulations regarding financial system.

At last we can say that, Indian financial system mostly responsible for economic growth and development of the economy.

\section{REFERENCE}

[1] Allen, F., Chakrabarti, R and De, S. (2007). India's Financial System.

[2] Arora, S.S, and Leach, J. (2005). Towards Building an Inclusive Financial Sector: Lessons from South Africa. Economic and Political weekly. Vol.40. 17, pp:17261730.

[3] Demirguc-kunt, A.(2006). Finance and Economic Development: Policy Choices for Developing Countries. World Bank Policy Research Working Paper 3955, WPS3955.

[4] Dutt, G. and Mahajan, A. (2016). Dutt \& sundram's Indain Economy. S. Chand \& Company Pvt. Ltd. 72nd Revised Edition.

[5] Gupta S.K., Aggerwal N. \& Gupta N.(2012). Financial Institutions and Markets, Kalyani Punlishers.

[6] Gomez, C.(2013). Financial Markets, Institutions and Financial Services. PHI.

[7] Hanson, J.A. and Katuria, S. (1999). India's Financial System: The challenges of Reform. Oxford University Press, New Delhi.

[8] Levine Ross. Financial Development and Economic Growth, Journal of Economic Literature. 1997; 3592:688-726.

[9] Chandra Prasanna. Financial Management, Tata McGraw Hill, New Delhi, 2016.

\section{BIOGRAPHY}

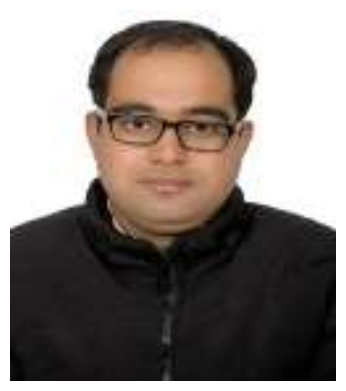

Manoj Kumar is BCA., MCA., MBA., M.Phil. He is working as a Assistant Professor in Department of Business Management and Commerce at IEC University Baddi, Himachal Pradesh, India. 